Н. В. Капелюш, В. П. Бессонова

Запорізький наиіональний університет, Дніпропетровський державний аграрний університет

\title{
СЕРЕДОВИЩЕОЧИЩУВАЛЬНА РОЛЬ PLATANUS ORIENTALIS У НАСАДЖЕННЯХ САНІТАРНО-ГІГІЕНІЧНОГО ПРИЗНАЧЕННЯ
}

Подано аналіз повітроочищувальної ролі платанів (Platanus orientalis L.) в умовах забруднення навколишнього середовища. Дослідження показали достатньо високу здатність платанів до очищення повітря від сполук сірки, фтору, хлору та фенолів.

The analysis of air clearing role of Platanus orientalis L. trees under conditions of environmental contamination is represented. The research has shown sufficiently high ability of the plane-trees to the air cleansing from compounds of sulfur, fluorine, chlorine and phenols.

\section{Ветуп}

Унаслідок функціонування промислових підприємств до атмосфери надходить велика кількість шкідливих газоподібних речовин. Найбільше небезпечні фториди, хлориди, газоподібні сполуки сірки, оксиди азоту. Вихлопні гази автотранспорту самостійне джерело забруднення.

Головними санітарами міського повітря вважаються рослинні насадження. Ще у 1938-1967 роках у роботах А. А. Адамової, Н. Г. Кротової, В. А. Рязанова визначалася середовищеочищувальна роль рослин від токсичних газів, що надходять у повітря внаслідок функціонування промислових підприємств [1; 12; 15]. Результати польових та лабораторних дослідів показали, що листя рослин поглинає із повітря $\mathrm{SO}_{2}, \mathrm{H}_{2} \mathrm{~S}$ [4; 8; 11], $\mathrm{NH}_{3}$ [14], феноли [5; 7], оксиди азоту [7], інші органічні та неорганічні сполуки та трансформує їх у тканинах рослинного організму $[4 ; 7 ; 16]$.

Останнім часом для озеленення вулиць промислових міст південного сходу України застосовують платан східний. Він формує добре розвинену густу крону, досить толерантний до забруднення [9]. Проте його середовищеочищувальна здатність не вивчена. Мета даного дослідження - проаналізувати газоакумулювальну здатність листків платана східного за умов забруднення повітря інгредієнтами промислових викидів та вихлопів автотранспорту. Одержані результати можуть бути застосовані в озелененні територій із різним типом забруднення довкілля, для екологічних розрахунків та оцінки реальних можливостей рослинності в оздоровленні повітря.

\section{Матеріал і методи досліджень}

Проведено порівняльний аналіз накопичення інгредієнтів техногенних викидів у листі цього інтродукованого виду та аборигенних видів Acer pseudoplatanoides (клен гостролистий) та Tilia cordata (липа серцелиста). Як об'єкти дослідження використовували вид Platanus orientalis L. Дослідні рослини зростали на ділянках санітарно-гігієнічного призначення, що відрізнялися рівнем запиленості та якісним складом забруднення. Перша ділянка знаходилася у зоні поширення емісій металургійного комбінату. У цьому районі концентрації фенолу, $\mathrm{SO}_{2}, \mathrm{NO}_{2}$ та важких металів перевищують ГДК у 1,3-4,3 раза. Ділянка 2 розташована поблизу алюмінієвого заводу, який викидає 12787 тонн промислових викидів на рік. Основними забруднювачами у цих викидах є фториди, диоксиди азоту, сірчасті та хлористі сполуки, які перевищували ГДК у 1,6-4,8 раза. Ділянка 3 обрана на території трансформаторного

(C) Н. В. Капелюш, В. П. Бессонова, 2007

Вісник Дніпропетровського університету. Біологія, екологія.

Vìsnik Dnìpropetrovs'kogo unìversitetu. Serìa Bìologîa, ekologîâ Visnyk of Dnipropetrovsk University. Biology, ecology. Vìsn. Dnìpropetr. Unìv. Ser. Bìol. Ekol. 2007. 15(1).

ISSN 2310-0842 print ISSN 2312-301X online www.ecology.dp.ua 
заводу, який дає 107 т промислових викидів на рік. Максимальну концентрацію у цих викидах складають оксиди нітрогену $(49,9$ т), ксилол $(4,2$ т), толуол $(1,4$ т), які перевищують ГДК у 1,3-2,5 раза. Ділянка 4 розташована поблизу заводу “Іскра”. У цьому районі концентрації оксиду нітрогену $(44,8$ т), ксилолу $(4,1$ т), толуолу $(1,8$ т) перевищували ГДК у $0,8-1,2$ раза. Ділянка 5 розташована поблизу автомобільного шляху 3 інтенсивним рухом автомобільного транспорту.

Листя для аналізу відбирали з південно-східного боку дерев із середньої частини крони (2-3-й листки пагонів відновлення). Визначення сірки проводили ваговим, хлору - аргентометричним методами [3], фенолів - за прописом Л. Г. Долгової, Ж. Т. Козюкіної [5]. Кількість фтору визначали за Л. А. Хаземовою зі співавторами [20]. Накопичення сірки, фтору, хлору, фенолів проводили щомісячно протягом вегетації рослин. Кількісні показники ї акумуляції перераховували на фітомасу листків дерева. Фітомасу визначали за Ю. Л. Цельникер [21].

\section{Результати та їх обговорення}

Найважливішими компонентами забруднювачів повітря, що містять сірку, $є$ оксид сірки, сірководень та аерозолі сульфатів. Сірка - важливий мікроелемент, роль якого у метаболізмі рослин надзвичайно велика. Кількість цього елемента у період завершення ростових процесів листків Platanus orientalis (рис. 1) у контрольному варіанті дещо нижча, ніж після їх розгортання. Це, можливо, пояснюється ефектом "розбавлення", коли надходження сірки до листків відбувається менш інтенсивно, ніж збільшується маса даного органа. Надалі, 3 досягненням цими органами постійної величини, кількість елемента дещо підвищується й у наступні місяці суттєво не змінюється.

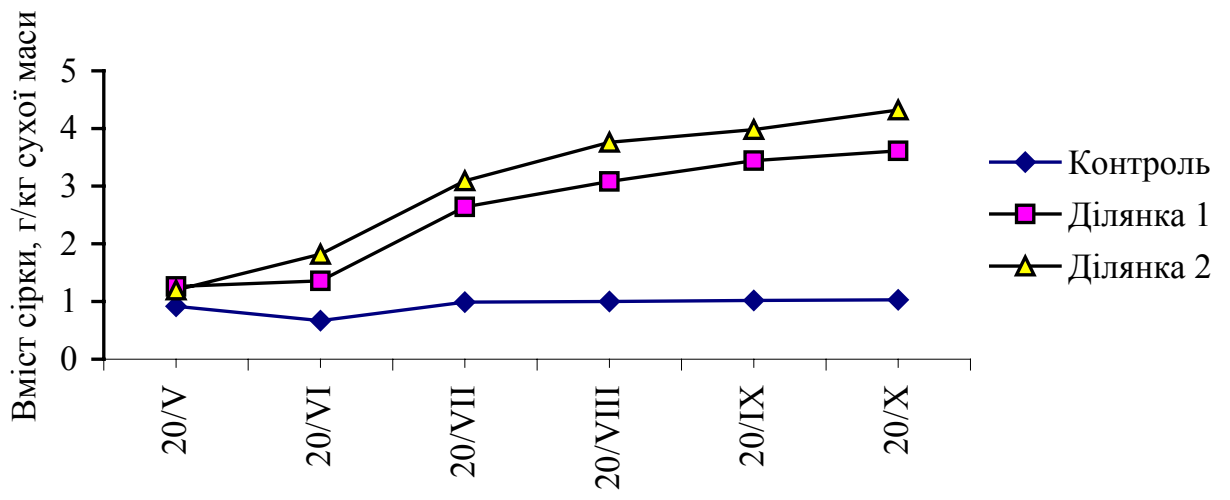

Рис. 1. Динаміка вмісту сірки у листках $P$. orientalis

Інша динаміка сірки спостерігається у листках рослин дослідних варіантів. Кількість елемента поступово зростає протягом усієї вегетації на обох ділянках. На початку вегетації (травень) акумуляція сірки виражається меншою величиною, ніж у наступні місяці. Найзначніше кількість елемента збільшилася у листках обох дослідних ділянок у період з 15 червня по 15 липня. Якщо у травні його вміст становив 136,9 (ділянка 1) та 130,4 \% (ділянка 2) до контрольних значень, то у липні ця величина дорівнює 223,9 та 271,6 \% відповідно. Слід враховувати, що рушійною силою поглинання рослиною газоподібних сполук сірки, як і інших забруднювачів, $€$ дифузія молекул головним чином через продихи [13; 16]. Чим сильніше опушені листки, тим менше вони поглинають $\mathrm{SO}_{2}$ [2]. У P. orientalis листки на початку вегетації мають сильне опушення, яке потім обвітрюється, тобто кількість волосків значно

60

Вісник Дніпропетровського університету. Біологія, екологія.

Vìsnik Dnìpropetrovs'kogo unìversitetu. Serîâ Bìologîa, ekologiâ Visnyk of Dnipropetrovsk University. Biology, ecology. Vìsn. Dnìpropetr. Unìv. Ser. Bìol. Ekol. 2007. 15(1).

ISSN 2310-0842 print ISSN 2312-301X online www.ecology.dp.ua 
зменшується. Цим і можна пояснити більші темпи акумуляції сірки у середині та другій половині вегетації, ніж на її початку.

Найвищі показники вмісту сірки в листках рослин дослідних варіантів виявлені в кінці вегетаційного періоду. Так, у рослин ділянки 1 (Парк металургів м. Запоріжжя) вміст сірки у жовтні складає $286 \%$ до ії кількості на цій же ділянці в травні, у рослин ділянки 2 (у зоні емісії алюмінієвого заводу) - $360 \%$.

Найвищий вміст сірки у листках рослин $P$. orientalis (табл. 1) виявлений на ділянці 2 (4,32 $\pm 0,21$ г/кг сухої ваги), де забруднення повітря сполуками сірки найзначніше. У рослин цього варіанта кількість елемента в одиниці маси листка зростає у 3,6 раза порівняно 3 контролем. Найменше накопичення сірки визначено на ділянках 4 та 5 із нижчим рівнем забруднення даним інгредієнтом промислових викидів. Отже, при зростанні ступеня забруднення повітря сполуками сірки вміст елемента у листках збільшується.

Таблиия 1

Накопичення забруднювачів повітря у листках деревних рослин за період вегетації

\begin{tabular}{|c|r|r|r|r|}
\hline Варіант & $\begin{array}{c}F, \text { мг/кг } \\
\text { сухоі маси }\end{array}$ & $\begin{array}{c}C l, \text { г/кг } \\
\text { сухої маси }\end{array}$ & $\begin{array}{c}S, \text { г/кг } \\
\text { сухої маси }\end{array}$ & $\begin{array}{c}\text { Фенол, мг/кг } \\
\text { сухої маси }\end{array}$ \\
\hline \multicolumn{5}{|c|}{ P. orientalis } \\
\hline Контроль & $1,62 \pm 0,25$ & $1,61 \pm 0,15$ & $1,02 \pm 0,18$ & $50,60 \pm 0,44$ \\
Ділянка 1 & $139,93 \pm 1,12$ & $5,56 \pm 0,29$ & $3,61 \pm 0,26$ & $426,00 \pm 6,32$ \\
Ділянка 2 & $396,72 \pm 2,36$ & $10,40 \pm 0,32$ & $4,32 \pm 0,21$ & $595,60 \pm 5,26$ \\
Ділянка 3 & $75,03 \pm 1,31$ & $7,90 \pm 0,61$ & $2,33 \pm 0,36$ & $115,30 \pm 7,36$ \\
Ділянка 4 & $17,78 \pm 0,49$ & $3,20 \pm 0,24$ & $1,45 \pm 0,24$ & $216,16 \pm 8,11$ \\
Ділянка 5 & $19,23 \pm 0,52$ & $4,70 \pm 0,30$ & $1,65 \pm 0,19$ & $62,20 \pm 0,48$ \\
\hline \multicolumn{5}{|c|}{ A.pseudoplatanoides } \\
\hline Контроль & $2,15 \pm 0,12$ & $2,10 \pm 0,13$ & $0,90 \pm 0,11$ & $4,68 \pm 0,56$ \\
Ділянка 1 & $146,45 \pm 1,10$ & $6,46 \pm 0,11$ & $4,56 \pm 0,12$ & $518,11 \pm 5,62$ \\
Ділянка 2 & $420,50 \pm 2,11$ & $15,31 \pm 0,25$ & $5,90 \pm 0,14$ & $1845,24 \pm 18,06$ \\
Ділянка 3 & $99,86 \pm 1,44$ & $11,80 \pm 0,46$ & $3,84 \pm 0,52$ & $126,62 \pm 7,21$ \\
Ділянка 4 & $42,51 \pm 0,64$ & $8,20 \pm 0,32$ & $3,10 \pm 0,22$ & $236,24 \pm 8,32$ \\
Ділянка 5 & $46,12 \pm 0,58$ & $9,80 \pm 0,26$ & $3,32 \pm 0,18$ & $8,52 \pm 0,44$ \\
\hline \multicolumn{5}{|c|}{ T. cordata } \\
\hline Контроль & $1,86 \pm 0,09$ & $2,45 \pm 0,12$ & $1,25 \pm 0,14$ & $4,12 \pm 0,63$ \\
Ділянка 1 & $150,40 \pm 2,30$ & $7,24 \pm 0,14$ & $4,40 \pm 0,20$ & $512,00 \pm 5,14$ \\
Ділянка 2 & $431,20 \pm 3,20$ & $18,19 \pm 1,10$ & $5,31 \pm 0,18$ & $1741,00 \pm 16,89$ \\
Ділянка 3 & $112,46 \pm 1,52$ & $12,60 \pm 0,84$ & $3,62 \pm 0,24$ & $128,26 \pm 7,08$ \\
Ділянка 4 & $58,16 \pm 0,86$ & $9,60 \pm 0,28$ & $2,86 \pm 0,12$ & $229,00 \pm 8,12$ \\
Ділянка 5 & $61,12 \pm 0,24$ & $11,40 \pm 0,33$ & $2,98 \pm 0,21$ & $8,56 \pm 0,52$ \\
\hline
\end{tabular}

Газоподібний хлор виділяється в атмосферу при різних технологічних процеcax багатьох підприємств. Він викидається набагато рідше, ніж $\mathrm{HCl}$. Але час від часу мають місце неорганізовані аварійні викиди. Газоподібний хлор здатний надходити у рослини з повітря через продихи. При тривалій емісії відносно низьких концентрацій $\mathrm{HCl}$ в атмосферу листки рослин адсорбують цю сполуку разом із солями, що містять іони хлору. Відкладання іонів $\mathrm{Cl}^{\top}$ відбувається переважно в апікальних або крайових ділянках листка. Вважається, що аналіз цих органів на загальний вміст іонів хлору ефективний метод діагностики хронічного впливу $\mathrm{HCl}$ та хлору [18].

Хлор - фізіологічно необхідний елемент, що міститься у мікрокількостях у всіх органах рослин. У листках контрольних рослин вміст елемента протягом вегетації підвищується (рис. 2). Подібний характер динаміки накопичення хлору має місце і в листках рослин, що зростали за умов забруднення атмосферного повітря. На дослідних ділянках із техногенним забрудненням повітря темпи збільшення кількості елемента в листках дослідних рослин набагато вищі. Найзначніше накопи-

Вісник Дніпропетровського університету. Біологія, екологія.

Vìsnik Dnìpropetrovs'kogo unìversitetu. Serìâ Bìologîâ, ekologîâ Visnyk of Dnipropetrovsk University. Biology, ecology. Vìsn. Dnìpropetr. Unìv. Ser. Bìol. Ekol. 2007. 15(1).

ISSN 2310-0842 print ISSN 2312-301X online www.ecology.dp.ua 
чення хлору за вегетацію на одиницю маси виявлено у рослин поблизу алюмінієвого комбінату, який межує 3 металургійним промисловим комплексом (див. табл. 1). Концентрація елемента в листках становить 645,9 \% від контрольних значень.

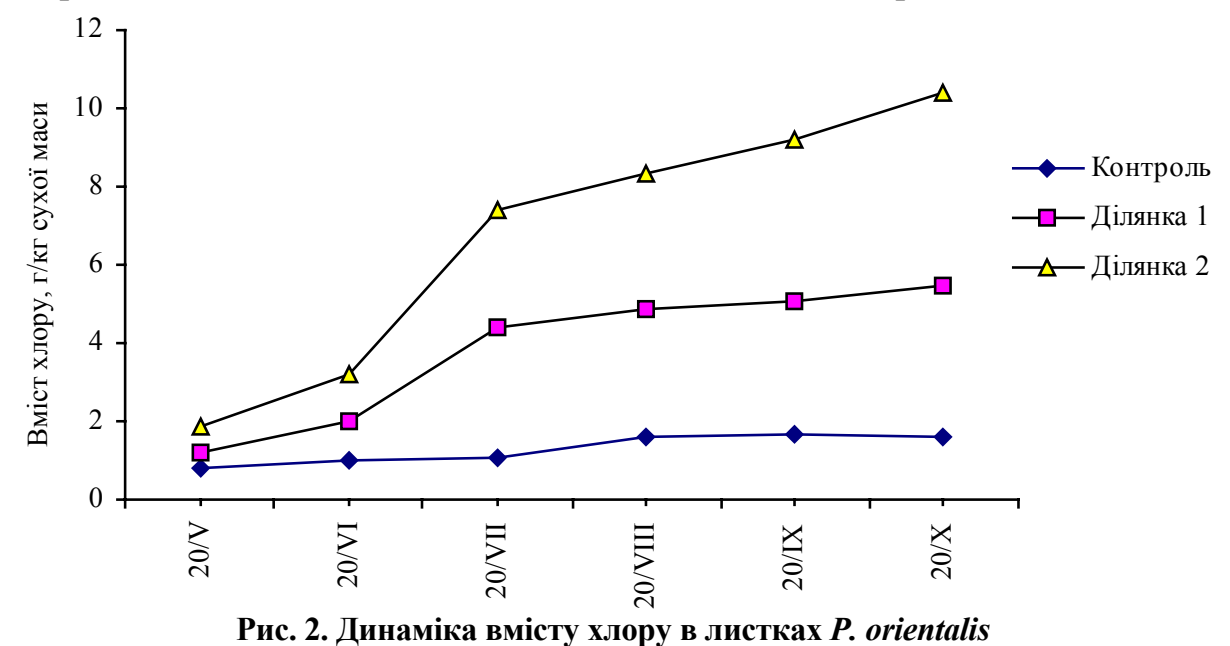

Значне накопичення хлору відбувається у листках рослин, що зростають на території трансформаторного заводу та Парку металургів $(490,7$ та $345,3 \%$ від контрольних значень). Слід зазначити, що у листках листках P. orientalis Парку металургів рівень накопичення хлору майже не відрізняється від концентрації у рослин вуличного насадження, хоча останні ростуть на відстані 5 км від промислових джерел забруднення. Це пов'язано 3 великою кількістю хлоридів (магнію, кальцію, натрію), що надходять у грунти при використанні солей для боротьби з ожеледицею. Зазвичай одноразово на $1 \mathrm{~m}^{2}$ дорожнього покриття використовують 50-70 г, а за зимовий період - від 0,6 до 2,7 кг солі [2]. У м. Запоріжжя кожної зими використовують до 320 т/рік суміші проти ожеледиці.

Накопичення хлору в листках $P$. orientalis у перерахунку на дерево відображає середовищеочищувальну здатність рослин (табл. 2). Кількість елемента, що накопичує листкова маса одного дерева за вегетацію, становить від 38,4 на ділянці 4 (територія заводу “Іскра") до 94,4 г/кг на ділянці 2 (територія алюмінієвого комбінату).

Головне джерело надходження фтору у навколишнє середовище - алюмінієві заводи, у меншій мірі - підприємства, що виготовляють керамічні, емалеві, цегляні вироби тощо. Значне поглинання сполук фтору листками обумовлене перш за все доброю розчинністю у воді та високою реакційною здатністю цих речовин. Рослини поглинають фтор із атмосферного повітря ефективніше, ніж будь-який інший полютант [22].

За результатами наших досліджень, у листках рослин відносно чистої зони концентрація фтору незначна. Найнижча вона у травні - 0,36 мг/кг сухої маси листків (рис. 3). Кількість фтору протягом вегетації підвищується, особливо восени. У жовтні вона складає 3,69 мг/кг. Отримані значення природного вмісту фтору в листках $P$. orientalis значно нижчі за максимально можливі за літературними даними для рослин, які зростають у вільних від промисловості районах. Максимальний природний вміст фторидів у таких рослин - до 20 мг/кг [23; 24].

Характер змін кількості фтору у процесі вегетації у листках P. orientalis дослідних ділянок такий, як у контролі. Спостерігається підвищення вмісту елемента 3 травня по жовтень. Однак концентрація фітотоксиканта в листках рослин техногенних територій значно вища.

Вісник Дніпропетровського університету. Біологія, екологія. Vìsnik Dnìpropetrovs'kogo unìversitetu. Serìâ Bìologiâ, ekologìâ Visnyk of Dnipropetrovsk University. Biology, ecology. Vìsn. Dnìpropetr. Unìv. Ser. Bìol. Ekol. 2007. 15(1).

ISSN 2310-0842 print ISSN 2312-301X online www.ecology.dp.ua 
Як видно 3 табл. 1, за вегетацію у листках рослин дослідних ділянок накопичується різна кількість фтору, що визначається рівнем забруднення. Найвищий він на ділянці 2, розташованій у сфері прямої дії викидів алюмінієвого заводу.

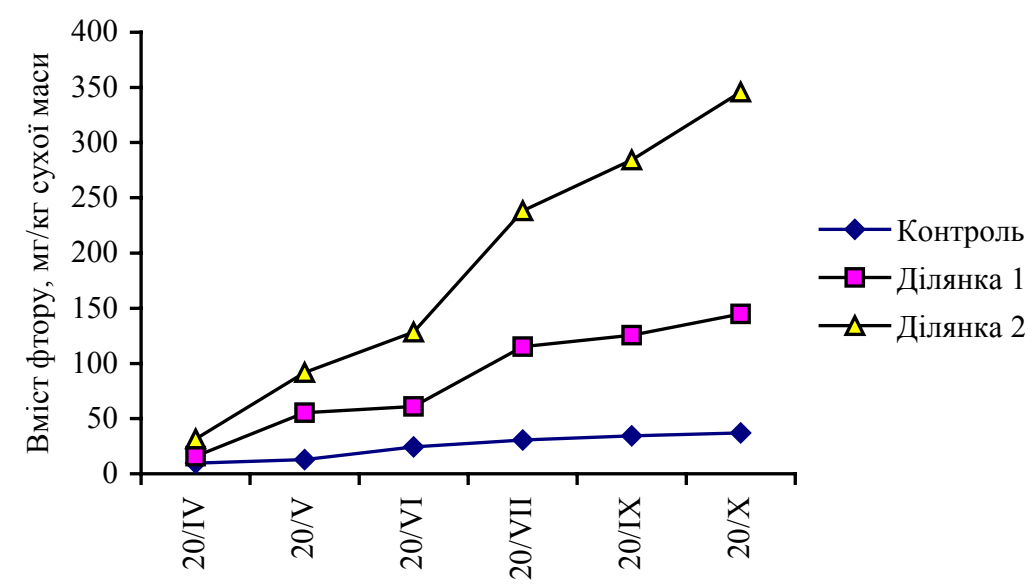

Рис. 3. Динаміка вмісту фтору в листках $P$. orientalis

Середовищеочищувальна роль деревних рослин за період вегетації у перерахунку на дерево (сухої маси)

\begin{tabular}{|c|c|c|c|c|}
\hline Варіант & $F$, мг & $C l$, г & $S$, г & Фенол, мг \\
\hline \multicolumn{5}{|c|}{ P. orientalis } \\
\hline Контроль & $16,71 \pm 2,08$ & $17,63 \pm 1,46$ & $11,22 \pm 1,42$ & $561,00 \pm 4,27$ \\
Ділянка 1 & $1417,08 \pm 20,31$ & $56,12 \pm 4,27$ & $36,41 \pm 2,14$ & $4345,21 \pm 19,36$ \\
Ділянка 2 & $3726,00 \pm 35,16$ & $94,37 \pm 10,16$ & $48,61 \pm 2,46$ & $6697,86 \pm 21,15$ \\
Ділянка 3 & $862,89 \pm 15,64$ & $75,85 \pm 8,11$ & $26,79 \pm 1,14$ & $1322,56 \pm 51,46$ \\
Ділянка 4 & $189,36 \pm 4,27$ & $38,41 \pm 3,44$ & $17,41 \pm 2,02$ & $2592,04 \pm 11,32$ \\
Ділянка 5 & $207,69 \pm 6,21$ & $49,96 \pm 6,11$ & $17,82 \pm 1,31$ & $669,60 \pm 8,63$ \\
\hline \multicolumn{5}{|c|}{ A.pseudoplatanoides } \\
\hline Контроль & $15,58 \pm 0,80$ & $15,22 \pm 1,26$ & $6,23 \pm 1,11$ & $48,16 \pm 3,26$ \\
Ділянка 1 & $872,84 \pm 18,21$ & $41,48 \pm 5,24$ & $27,17 \pm 1,26$ & $2864,52 \pm 36,28$ \\
Ділянка 2 & $2184,00 \pm 56,24$ & $79,61 \pm 8,64$ & $30,68 \pm 2,06$ & $8256,66 \pm 52,14$ \\
Ділянка 3 & $528,32 \pm 12,76$ & $65,18 \pm 5,22$ & $21,46 \pm 0,84$ & $964,34 \pm 28,64$ \\
Ділянка 4 & $146,23 \pm 2,53$ & $24,62 \pm 1,26$ & $14,28 \pm 0,86$ & $1236,24 \pm 12,52$ \\
Ділянка 5 & $184,56 \pm 5,23$ & $32,66 \pm 4,82$ & $14,53 \pm 0,92$ & $48,62 \pm 6,64$ \\
\hline \multicolumn{5}{|c|}{ T. cordata } \\
\hline Контроль & $13,48 \pm 0,56$ & $15,45 \pm 1,13$ & $7,88 \pm 1,34$ & $32,27 \pm 3,24$ \\
Ділянка 1 & $810,95 \pm 16,14$ & $25,41 \pm 2,36$ & $23,36 \pm 1,84$ & $2116,32 \pm 26,68$ \\
Ділянка 2 & $2026,64 \pm 54,32$ & $85,49 \pm 8,64$ & $24,95 \pm 1,68$ & $7432,54 \pm 46,16$ \\
Ділянка 3 & $508,62 \pm 14,56$ & $62,38 \pm 4,22$ & $18,64 \pm 0,87$ & $628,37 \pm 24,06$ \\
Ділянка 4 & $128,34 \pm 3,32$ & $21,52 \pm 1,08$ & $12,08 \pm 0,36$ & $886,36 \pm 44,06$ \\
Ділянка 5 & $168,47 \pm 4,22$ & $28,42 \pm 3,56$ & $12,46 \pm 0,52$ & $32,56 \pm 3,18$ \\
\hline
\end{tabular}

Аналіз накопичення фтору за вегетацію на одиницю маси показує, що за ступенем збільшення його у листі $P$. orientalis дослідні ділянки розташовуються так: ділянка $3<$ ділянка $1<$ ділянка 2 . У листі рослин, що зростали на території радіозаводу (ділянка 4) та у вуличних насадженнях (ділянка 5) також виявлено незначне накопичення цього забруднювача. Рослини звичайно поглинають відносно мало фторидів із грунту, навіть якщо їх уміст високий. При цьому корені в основному акумулюють фториди з грунту, а листя - 3 атмосфери [19]. Тому можна вважати, що більша кількість фтору, що акумулюється у листі, надходить з атмосфери.

Вісник Дніпропетровського університету. Біологія, екологія.

Vìsnik Dnìpropetrovs'kogo unìversitetu. Serìa Bìologîa, ekologîâ Visnyk of Dnipropetrovsk University. Biology, ecology. Vìsn. Dnìpropetr. Unìv. Ser. Bìol. Ekol. 2007. 15(1).

ISSN 2310-0842 print ISSN 2312-301X online www.ecology.dp.ua 
Загальна здатність до накопичення фтору асиміляційною поверхнею одного дерева наведена у табл. 2. Одне дерево P. orientalis акумулює від 189,4 мг фтору на ділянці 4, до 3726,0 мг - на ділянці 2.

Фенол та його похідні - поширені токсичні забруднювачі довкілля. Рослини здатні поглинати їх із повітря [5; 11] і трансформувати у природні метаболіти [7]. Нами виявлено підвищення кількості фенолу стосовно контрольних значень у листі дерев P. orientalis, що зростали на ділянках 1, 2, 3 та 4 (табл. 1). Найбільше накопичення фенолу за вегетацію на одиницю маси визначено у листі рослин ділянки 2 (поблизу алюмінієвого заводу) та ділянки 1 (Парк металургів). У листі рослин ділянки 2 їх кількість перевищує контрольні значення у 8,4 раза, на ділянці 1 - у 11,7 раза. Це корелює 3 найсуттєвішим рівнем забруднення повітря фенольними сполуками на обстежених ділянках порівняно з іншими моніторинговими точками. Значення вмісту фенолів у листі рослин контрольного варіанта і вуличного насадження (ділянка 5) статистично не відрізняються.

Дані про накопичення фенолу у листках $P$. orientalis за вегетацію у перерахунку на дерево (табл. 2) вказують на достовірні розбіжності за ступенем акумуляції даної сполуки між рослинами різних промислових ділянок.

Дослідження динаміки накопичення фенолу в листках (рис. 4) свідчать про те, що в кінці вегетації вміст цієї сполуки значно підвищується. В. П. Тарабрін зі співавторами [17] також відмічають меншу кількість чужорідних фенолів у листі ряду рослин у першій половині вегетаційного періоду порівняно з пізнішими строками, що автори пояснюють змиванням аерозолів фенолів із поверхні листків дощами, які випадали у цей період. Поступове підвищення вмісту фенолу у листі рослин спостерігали Л. Г. Долгова та Ж. Т. Козюкіна [5].

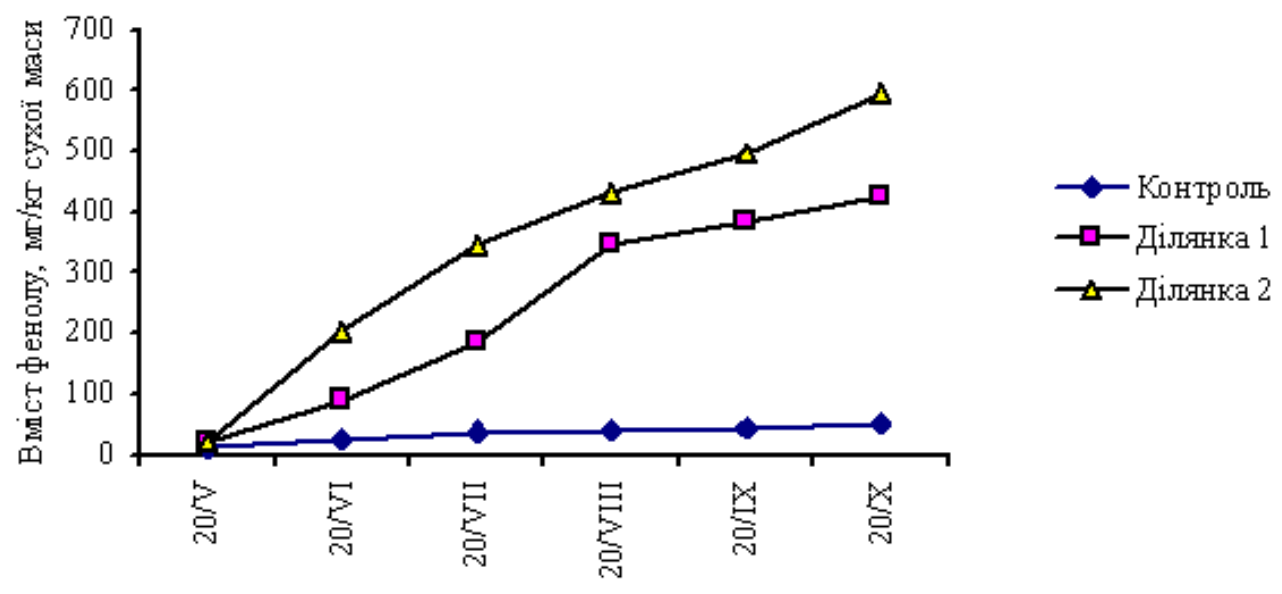

Рис. 4. Динаміка вмісту фенолу у листі P. orientalis

Фенол, який надходить у рослини, іммобілізується у тих органах, на які він діє безпосередньо. При внесенні фенолів у живильне середовище він не пересувався у надземні органи дослідних рослин (дуб звичайний, каштан кінський звичайний). Така ж картина виявлена і при фумігації рослин парами фенолу. У стеблах і коренях цей токсикант не накопичувався [19]. Отже, визначена кількість фенолів, що міститься в листі $P$. orientalis, відображає процес поглинання їх із повітря листям.

Порівняння газопоглинальної здатності листя P. orientalis та таких видів як A. pseudoplatanoides та T. cordata на одиницю сухої маси свідчить, що у платана вона дещо менша (табл. 1). Це викликає менше пошкодження листків, що дозволяє рослині зберігати функціональну активність листкової поверхні до пізньої осені. Менше

Вісник Дніпропетровського університету. Біологія, екологія.

Vìsnik Dnìpropetrovs'kogo unìversitetu. Seriâ Bìologîa, ekologîâ Visnyk of Dnipropetrovsk University. Biology, ecology. Vìsn. Dnìpropetr. Unìv. Ser. Bìol. Ekol. 2007. 15(1).

ISSN 2310-0842 print ISSN 2312-301X online www.ecology.dp.ua 
поглинання забруднювачів порівняно 3 вищевказаними видами можна пов'язати 3 тим, що листки P. orientalis мають товстішу кутикулу та значне опушення, особливо у першу половину вегетації. Крім того, за умов забруднення довкілля будова листка у P. orientalis набуває ксероморфної структури [10]. Але, враховуючи велику вегетативну масу та вищий рівень морфологічної стійкості P. orientalis порівняно 3 A. pseudoplatanoides та T. cordata, акумуляція листками фітотоксикантів за вегетацію у перерахунку на дерево вища, ніж у аборигенних видів.

\section{Висновки}

Акумуляція фітотоксикантів листям $P$. orientalis за вегетацію у перерахунку на дерево значно більша, ніж у аборигенних видів A.pseudoplatanoides та T. cordata. Аналіз повітроочищувальної ролі платанів в умовах забруднення навколишнього середовища показав достатньо високу здатність платанів до очищення повітря.

\section{Бібліографічні посилання}

1. Адамова Н. А. Защитная роль зеленых насаждений в отношении пыли и дыма // Жилой квартал. - М.: Медицина, 1938. - Т. 11. - С. 36-48.

2. Артамонов В. И. Растения и чистота природной среды. - М.: Наука, 1986. -172 с.

3. Бессонова В. П. Методи фітоіндикації в оцінці екологічного стану довкілля. - Запоріжжя: Вид-во ЗДУ, 2001. - 196 с.

4. Гетко Н. В. Растения в техногенной среде. Структура и функция ассимиляционного аппарата. - Минск: Наука и техника, 1989. - 208 с.

5. Долгова Л. Г. До питання про біологічне очищення атмосфери в умовах коксохімічних підприємств / Л. Г. Долгова, Ж. Т. Козюкіна // Укр. бот. журн. - 1972. - Т. 29, № 2. C. $172-175$.

6. Долгова Л. Г. Методические указания к выполнению лабораторных работ по спецкурсу «Физиологические основы устойчивости растений к неблагоприятным факторам среды» / Л. Г. Долгова, Ж. Т. Козюкіна, В. Н. Кучма. - Д.: ДГУ, 1988. - 12 с.

7. Дурмишидзе С. В. Метаболизм растениями некоторых органических соединений, загрязняющих атмосферу // Прикладная биохимия и микробиология. - 1977. - Т. 13, № 6. C. $838-846$.

8. Илькун Г. М. Загрязнители атмосферы и растения. - К.: Наукова думка, 1978. - 217 с.

9. Капелюш Н. В. Динаміка каротиноїдів у листках рослин Platanus orientalis L., що знаходяться під впливом викидів автотранспорту / Н. В. Капелюш, В. П. Бессонова // Питання біоіндикації та екології. - Запоріжжя: ЗДУ, 2004. - Вип. 9, № 1. - С. 95-104.

10. Капелюш Н. В. Зміна анатомічних показників листків Platanus orientalis L. під дісю промислових емісій (техногенного навантаження) / Н. В. Капелюш, В. П. Бессонова // Інтродукція рослин. - 2005. - № 1. - С. 81-87.

11. Красинский Н. П. Теоретические основы построения ассортимента газоустойчивых растений // Дымоустойчивость растений и дымоустойчивые ассортименты. - М.: Горький, 1950. - C. 9-109.

12. Кротова Н. Г. Влияние задымленности воздуха на рост и развите сосны в зоне ТСХА // Доскл. ТСХА. - 1959. - Вып. 29. - С. 12-26.

13. Мальхотра С. С. Биохимическое и физиологическое действие приоритетных загрязняющих веществ / С. С. Мальхотра, А. А. Хан // Загрязнение воздуха и жизнь растений. - Л.: Гидрометеоиздат, 1988. - С. 144-189.

14. Попов 3. А. Природные факторы в борьбе с загрязнением атмосферы / 3. А. Попов, К. И. Попов // Опыт и методы экологического мониторинга. - Пущино, 1978. - С. 78-82.

15. Рязанов В. А. Основные проблемы санитарной охраны атмосферного воздуха // Биологическое действие и гигиеническое значение атмосферных загрязнений. - М.: Медицина, 1967. - C. 132-138.

Вісник Дніпропетровського університету. Біологія, екологія.

Vìsnik Dnìpropetrovs'kogo unìversitetu. Serìâ Bìologîa, ekologìâ Visnyk of Dnipropetrovsk University. Biology, ecology. Vìsn. Dnìpropetr. Unìv. Ser. Bìol. Ekol. 2007. 15(1).

ISSN 2310-0842 print ISSN 2312-301X online www.ecology.dp.ua 
16. Сергейчик С. А. Экологическая физиология хвойных пород Беларуси в техногенной среде / С. А. Сергейчик, А. А. Сергейчик, Е. А. Сидорович. - Минск: Беларуская наука, 1989. - $199 \mathrm{c}$.

17. Тарабрин В. П. Использование зеленых насаждений для оптимизации среды в зоне загрязнения предприятий черной металлургии / В. П. Тарабрин, Л. В. Чернышева, Р. И. Пельтихина // Растения и промышленная среда. - Свердловск: Изд-во УГУ, 1984. - С. 101-106.

18. Тейлор К. О. Реакции высших растений на фотохимические и другие атмосферные загрязнители на организменном уровне // Загрязнение воздуха и жизнь растений. - Л.: Гидрометеоиздат, 1988. - С. 247-272.

19. Фитотоксичность органических и неорганических загрязнителей / В. П. Тарабрин, Е. И. Кондратюк, В. Г. Башкатов и др. - К.: Наукова думка, 1986. - 216 с.

20. Определение фтора в растительном организме / Л. А. Хаземова, Т. Л. Разовская, Н. В. Круглова, Т. К. Качалова // Агрохимия. - 1983. - № 6. - С. 66-72.

21. Цельникер Ю. Л. Определение листовой массы древостоев без отрывания листьев // Бот. журн. - 1963. - Т. 48, № 4. - С. 552-563.

22. Fate of air pollutants: removal of ethylene, sulpher dioxide and nitrogen dioxide, by soil / F. B. Abelesatal, L. E. Craker, L. E. Forrence, G. R. Leather // Science. - 1971. - Vol. 173. P. 914-916.

23. Jurkowska H. Skazenie gleb i roglin zwiazkami siarki i fluoru / H. Jurkowska, T. Litynski // Pr. Inst. mat., fir i chem. Pzubel. - 1984. - N 4. - S. 132-152.

24. Thomas M. D. The effect of fluoride on plants / M. D. Thomas, E. W. Alter // Handbuch der experimentallen Pharmakologie. - Berlin, Heidelberg, New York: Springer-Verlag, 1966. Vol. 20, N 1. - P. 231-366.

Надійшла до редколегії 20.09.2006

Вісник Дніпропетровського університету. Біологія, екологія.

Vìsnik Dnìpropetrovs'kogo unìversitetu. Serîâ Bìologìâ, ekologîâ

Visnyk of Dnipropetrovsk University. Biology, ecology. Vìsn. Dnìpropetr. Unìv. Ser. Bìol. Ekol. 2007. 15(1).

ISSN 2310-0842 print ISSN 2312-301X online www.ecology.dp.ua 